\title{
Cell Cycle Regulation of the c-Myc Transcriptional Activation Domain
}

\author{
ALPNA SETH, ${ }^{1} \dagger$ SHASHI GUPTA, ${ }^{1}$ AND ROGER J. DAVIS ${ }^{1,2 *}$ \\ Howard Hughes Medical Institute ${ }^{2}$ and Program in Molecular Medicine, Department of Biochemistry and \\ Molecular Biology, ${ }^{1}$ University of Massachusetts Medical School, Worcester, Massachusetts 01605
}

Received 2 March 1993/Returned for modification 9 April 1993/Accepted 22 April 1993

\begin{abstract}
The product of the c-myc gene (c-Myc) is a sequence-specific DNA-binding protein that has previously been demonstrated to be required for cell cycle progression. Here we report that the c-Myc DNA binding site confers cell cycle regulation to a reporter gene in Chinese hamster ovary cells. The observed transactivation was biphasic with a small increase in $G_{1}$ and a marked increase during the $S-$ to- $_{2} / M$ transition of the cell cycle. This cell cycle regulation of transactivation potential is accounted for, in part, by regulatory phosphorylation of the c-Myc transactivation domain. Together, these data demonstrate that c-Myc may have an important role in the progression of cells through both the $G_{1}$ and $G_{2}$ phases of the cell cycle.
\end{abstract}

Evidence has been obtained indicating an important functional role for the $\mathrm{c}-\mathrm{Myc}$ protein during cellular proliferation and differentiation $(22,70,82)$. For many years the function of c-Myc has been poorly understood. However, significant progress has recently been made towards understanding molecular details about the biological actions of c-Myc. Thus, it is now known that c-Myc can function as a transcription factor and that it is a sequence-specific DNAbinding protein with a transactivation domain, a basic region, and dimerization motifs that are required for interaction with a partner protein, $\operatorname{Max}(15,23,60,74,91$, 114). It has also been demonstrated that the functional form of the c-Myc protein is represented by the heterodimeric complex of c-Myc and Max $(3,4,14)$. Recent studies have shown that the c-Myc partner protein Max can also interact with at least two other proteins: Mad and Mxil $(7,119)$.

Treatment of quiescent cells with growth factors results in an increase in c-Myc expression (62). However, in growing cells, c-Myc is expressed constitutively $(28,49,94,112$, 116). The expression of Max is also constitutive during the cell cycle $(14,16,61,73,88,89)$. These observations suggest that the level of expression of the functional c-Myc-Max heterodimer is not regulated in growing cells. This conclusion has been confirmed by coimmunoprecipitation studies which demonstrate that the level of the c-Myc-Max complex is invariant during the cell cycle (16). Under these conditions of constitutive expression, the function of the c-Myc-Max complex could be regulated by competition for binding to c-Myc DNA-responsive elements (CACGTG) present within promoter sequences $(4,5,7,66,119)$. Alternatively, functional regulation could occur by a mechanism involving a posttranslational modification, such as phosphorylation (54, 55). Indeed, the phosphorylation state of c-Myc has been shown to be regulated during the cell cycle (71).

It is known that c-Myc is a substrate for at least two protein kinases: casein kinase II (72) and MAP kinase (2). The role of casein kinase II phosphorylation of c-Myc has not been defined (107), but it has been established that this protein kinase can inhibit DNA binding by Max homodimers

\footnotetext{
* Corresponding author.

$\dagger$ Present address: Department of Biochemistry and Molecular Biology, Harvard University, Cambridge, MA 02139.
}

(10). In contrast, phosphorylation of c-Myc at the MAP kinase site, Ser-62, positively regulates the c-Myc transactivation domain $(45,99,100)$. A regulatory role for this phosphorylation is consistent with the observation that Ser-62 is the major site of phosphorylation of the c-Myc protein in vivo (45). Significantly, Ser-62 is not only a substrate for phosphorylation by MAP kinase but also a substrate for in vitro phosphorylation by the cyclin-dependent protein kinase p34 $4^{c d c 2}(99)$. Thus, although expression of c-Myc is constitutive during the cell cycle, it is possible that the function of $\mathrm{c}-\mathrm{Myc}$ is subject to cell cycle-dependent regulation by phosphorylation.

Cells that express high levels of c-Myc generally exhibit reduced requirements for growth factors $(6,68,104,105)$ and exhibit higher growth rates $(68,79)$ characterized by a shortened length of the $G_{1}$ phase of the cell cycle (58). The expression of c-Myc can also overcome growth arrest $(6,44$, 65). Thus, c-Myc is a critical protein that is required for normal cell cycle progression $(95,103)$. In contrast, exit from the cell cycle may require down-regulation of c-Myc expression. One example is provided by the action of transforming growth factor beta (TGF- $\beta$ ) to cause both growth arrest and c-Myc down-regulation $(21,83,84)$. Treatment of cultured cells with antisense c-myc oligonucleotides or with TGF- $\beta 1$ causes an inhibition of cellular proliferation by blocking entry of cells into $S$ phase $(50,51,83,84)$. The observation that antisense c-myc can initiate cellular differentiation (51) suggests that c-Myc down-regulation may also be mechanistically relevant to the process of differentiation. Strong support for this hypothesis is provided by the demonstration that $\mathrm{c}-\mathrm{Myc}$ overexpression can block terminal differentiation $(8,11,24,30,39,67,75,92)$. There are, however, several exceptions to the simple correlation between cellular proliferation or differentiation and the level of c-Myc expression $(31,32,52,56,64)$. One example of the complex relationship between c-Myc expression and cellular proliferation is provided by the possible role of c-Myc during apoptosis $(12,37$, 101).

Several lines of evidence indicate that c-Myc may have a role during the $G_{1}$ phase of the cell cycle $(50,58)$. For example, c-Myc has been shown to be sufficient to cause cells to enter $S$ phase $(6,34,35)$. Furthermore, the observation that c-Myc can overcome the $G_{1}$ growth arrest induced by $R b(42)$ demonstrates that $c-M y c$ does act at the $G_{1}$ phase 
of the cell cycle. However, these data do not indicate that the functional role of $c-M y c$ is restricted to $G_{1}$. Indeed, c-Myc may also function at other phases of the cell cycle (51). Consistent with this hypothesis is the observation that c-Myc can rescue a deficiency in BAF-BO3 cells which prevents progress of the cells beyond $\mathrm{S}$ phase after epidermal growth factor stimulation (103).

The purpose of this study was to evaluate the cell cycle regulation of c-Myc function as a transcription factor. We report that the level of transactivation oscillates as cells progress through the cell cycle and that there is a marked increase in transactivation during the $S-$ to $-G_{2} / M$ transition. The regulation of transactivation potential can be accounted for, in part, by changes in the phosphorylation state of c-Myc. Together, these data indicate that there may be an important function of $\mathrm{c}-\mathrm{Myc}$ during the $\mathrm{G}_{2}$ phase of the cell cycle.

\section{MATERIALS AND METHODS}

Materials. $\left[{ }^{32} \mathrm{P}\right]$ phosphate and ${ }^{125} \mathrm{I}$-protein A were from Dupont-New England Nuclear. $\left[{ }^{3} \mathrm{H}\right]$ thymidine was from ICN. Aphidicolin, hydroxyurea, and $o$-nitrophenyl- $\beta$-D-galactopyranoside were purchased from Sigma Chemical Co. (St. Louis, Mo.). Hoechst 33342 was from CalbiochemBehring Corp. (La Jolla, Calif.). Fetal bovine serum (FBS) was from Gibco-BRL Inc. Luciferin was purchased from Analytical Luminescence Labs (San Diego, Calif.). The polyclonal rabbit anti-GAL4 antibody was a gift from $\mathbf{M}$. Ptashne (Harvard University). The anti-Myc immunoglobulin $G$ was purified from serum that was obtained after immunization of a sheep with a bacterially expressed human c-Myc protein (residues 2 to 243) as an antigen.

Plasmids. The plasmids pM21 and pRSV-Neo were obtained from C. V. Dang (Johns Hopkins School of Medicine) and C. W. Woon (University of Massachusetts Medical School), respectively. The plasmids pCH110 and pUC13 were from Pharmacia-LKB Biotechnology Inc. The activator plasmids pGAL4/Myc and pGAL4/[Ala $\left.{ }^{62}\right] \mathrm{Myc}$ were constructed by using the vector pSG424 and have been described previously (2). The plasmids pSG424-Luc and pG5E1bLuc were prepared by cloning the luciferase gene from pGEM-Luc (Promega Biotech) into the vectors pSG424 and pG5E1bCAT, respectively, as described previously (100).

The plasmids pMyc0E1bLuc and pMyc1E1bLuc were prepared from pG5E1bLuc. The GAL4/E1b promoter was removed from pG5E1bLuc as a PstI and KpnI fragment and replaced with a double-stranded $20 \mathrm{mer}$ oligonucleotide that contains the E1b promoter TATA element (5' GAGGGTAT ATAATGTGGTAC $3^{\prime}$ and 5' CACATTATATACCCTCTG CA $3^{\prime}$ ) to create pMyc0E1bLuc. A c-Myc binding site (underlined) was inserted at the HindIII site of pMyc0 E1bLuc as a $26 \mathrm{mer}$ double-stranded oligonucleotide (5' AG CTTAACTGACCACGTGGTCAACTA $3^{\prime}$ and 5' AGCTT AGTTGACCACGTGGTCAGTTA $3^{\prime}$ ) to obtain the plasmid pMyc1E1bLuc.

Cell culture and transfection assays. COS-7 cells were subcultured in Dulbecco's modified Eagle's medium supplemented with $5 \%$ FBS, and transfections were performed by the DEAE-dextran method as previously described (2).

CHO cells were maintained in Ham's F-12 medium supplemented with 5\% FBS. Cells expressing GAL4/Myc or GAL4/[Ala $\left.{ }^{62}\right] \mathrm{Myc}$ activator protein together with the reporter plasmid (pG5E1bLuc) were obtained by cotransfecting $5 \mu \mathrm{g}$ of activator plasmid and $5 \mu \mathrm{g}$ of each plasmid together with $2 \mu \mathrm{g}$ of pRSVneo by the calcium phosphate technique. G418-resistant colonies were isolated and screened for the fusion protein expression and luciferase reporter activity. Cells were also cotransfected with pRSVNeo and (i) pG5E1bLuc (to monitor the basal expression of the reporter plasmid), (ii) pSG424-Luc (to monitor the activity of the activator expression vector), and (iii) pMyc1E1b Luc (to monitor reporter gene expression conferred by the c-Myc DNA binding site CACGTG).

CHO cells transfected with control DNA (pUC13), or with the activator plasmid alone, gave no measurable luciferase activity. In cells expressing the reporter plasmid (pG5E1b Luc) alone, the level of luciferase activity detected was very low $\left(10^{4}\right.$ light units $/ 10^{6}$ cells). This reflects the basal activity of the E1b promoter. Cotransfection of the activator and reporter plasmids resulted in cells that expressed a high level of luciferase activity ( $\sim 10^{7}$ light units $/ 10^{6}$ cells). Cells expressing the pMyclElbLuc reporter plasmid had an intermediate level of luciferase activity ( $10^{5}$ light units $/ 10^{6}$ cells).

Cell synchronization. CHO cells were seeded in $100-\mathrm{mm}$ dishes for luciferase assays, immunoblotting, and immunoprecipitation; $150-\mathrm{mm}$ tissue culture dishes were used for fluorescence-activated cell sorter analysis; and 6-well multidish plates were used for the analysis of $\left[{ }^{3} \mathrm{H}\right]$ thymidine incorporation. Log-phase cultures were synchronized at the $\mathrm{G}_{1} / \mathrm{S}$ boundary by treatment for $18 \mathrm{~h}$ with $1 \mu \mathrm{g}$ of aphidicolin per $\mathrm{ml}$ or $1 \mathrm{mM}$ hydroxyurea, washed three times with serum-free medium, transferred to complete medium for 10 $h$, and then growth arrested by incubation in medium containing aphidicolin or hydroxyurea for $18 \mathrm{~h}$. Hydroxyurea arrests cells near the $G_{1} / S$ boundary at a point distinct from aphidicolin arrest $(1,26,46,81,118)$. To arrest cells in the $G_{2}$ phase, the cells were presynchronized at $G_{1} / S$ by treatment with $1 \mathrm{mM}$ hydroxyurea for $18 \mathrm{~h}$, washed three times with serum-free medium, and then incubated for an additional 12 $\mathrm{h}$ in complete medium supplemented with $7.5 \mu \mathrm{g}$ of Hoechst 33342 dye per $\mathrm{ml}$ (113). To examine the possibility of delayed toxicity associated with the multistep synchronization procedures, cell proliferation was monitored by total cell count with a hemocytometer.

Analysis of cell synchrony. The synchrony of cells was monitored by assessing the cellular DNA content by flow cytometry, using a Becton Dickinson FACScan. For flow cytometric analysis, $6 \times 10^{6}$ cells were trypsinized, washed in phosphate-buffered saline, fixed in a solution of $95 \%$ cold ethanol, and stored at $4^{\circ} \mathrm{C}$. The fixed cells were stained with propidium iodide as described previously (111). The fluorescence intensity of propidium iodide, which is proportional to the cellular DNA content, was measured and analyzed with PC Lysys software (B. Woda, University of Massachusetts Medical School). To determine the time of DNA synthesis in synchronized cell cultures, the incorporation of thymidine into DNA was measured by pulse-labeling with $\left[{ }^{3} \mathrm{H}\right]$ thymidine $(1 \mu \mathrm{Ci} / \mathrm{ml})$ for $30 \mathrm{~min}$ in $2 \mathrm{ml}$ of medium. The cells were washed twice with ice-cold Krebs-Ringer HEPES (KRH) buffer $(128 \mathrm{mM} \mathrm{NaCl}, 5 \mathrm{mM} \mathrm{KCl}, 5 \mathrm{mM} \mathrm{MgSO}, 1.3 \mathrm{mM}$ $\mathrm{CaCl}_{2}, 50 \mathrm{mM}$ HEPES, $\mathrm{pH}$ 7.4) (HEPES is $N$-2-hydroxyethylpiperazine- $N^{\prime}$-2-ethanesulfonic acid) and then incubated in KRH supplemented with $2 \%$ trichloroacetic acid at $4^{\circ} \mathrm{C}$ for $12 \mathrm{~h}$ on a shaking platform. The cells were washed once with KRH-2\% trichloroacetic acid, three times with KRH, and once with ice-cold methanol. The cells were air dried and then solubilized with $1 \mathrm{ml}$ of $0.2 \mathrm{M} \mathrm{NaOH}$ for $60 \mathrm{~min}$ at room temperature. An aliquot $(500 \mu \mathrm{l})$ was removed and mixed with $100 \mu \mathrm{l}$ of $1 \mathrm{M} \mathrm{HCl}$ and $5 \mathrm{ml}$ of scintillation fluid 
(Optifluor; Packard). Radioactivity was measured in a Beckman scintillation counter.

Measurement of luciferase and $\beta$-galactosidase activity. The protein concentration in cell extracts was measured by the Bradford dye binding procedure (BioRad) with bovine serum albumin as a standard. Luciferase activity was measured by using $5 \mu$ l of cell extract with an Analytical Luminescence Laboratory (San Diego, Calif.) model 2010 luminometer (99) and expressed as light units per milligram of protein. The activity of $\beta$-galactosidase in COS cells was measured by mixing $15 \mu \mathrm{l}$ of cell extract with $3 \mu \mathrm{l}$ of $0.1 \mathrm{M} \mathrm{MgCl}_{2}-4.5 \mathrm{M}$ $\beta$-mercaptoethanol, $66 \mu \mathrm{l}$ of $4 \mathrm{mg}$ of $o$-nitrophenyl- $\beta$-Dgalactopyranoside per $\mathrm{ml}$, and $216 \mu \mathrm{l}$ of $0.1 \mathrm{M}$ sodium phosphate ( $\mathrm{pH} 7.5)$. The incubations were performed at $37^{\circ} \mathrm{C}$ for $5 \mathrm{~min}$ or until a faint yellow color appeared. The reactions were stopped by adding $500 \mu \mathrm{l}$ of $1 \mathrm{M} \mathrm{Na} \mathrm{CO}_{3}$ to each tube, and the optical density at $420 \mathrm{nM}$ was measured with a Pharmacia-LKB spectrophotometer.

Isolation of metabolically labeled phosphoproteins by immunoprecipitation. COS-7 cells in $100-\mathrm{mm}$ dishes were trypsinized $18 \mathrm{~h}$ posttransfection. The cells were pooled, reseeded into two $100-\mathrm{mm}$ dishes (one for Western blot [immunoblot] analysis and the second for metabolic labeling with inorganic $\left[{ }^{32} \mathrm{P}\right]$ phosphate). The cells were then incubated in Dulbecco's modified Eagle's medium containing 5\% FBS for $10 \mathrm{~h}$. Hydroxyurea $(1 \mathrm{mM})$ was added to the medium for $18 \mathrm{~h}$. The arrested cells were washed three times with serum-free medium and then incubated in serum-supplemented medium. During the last $4 \mathrm{~h}$ of incubation, the cells were transferred to phosphate-free modified Eagle's medium (Flow Labs Inc.) containing 1\% FBS and $2 \mathrm{mCi}$ of $\left.{ }^{32} \mathrm{P}\right]$ phosphate (Dupont-NEN) per ml. The cells were lysed, and the GALA fusion proteins were isolated by immunoprecipitation using an anti-GALA antibody and sodium dodecyl sulfate-polyacrylamide gel electrophoresis (SDS-PAGE) as described previously (2).

Phosphopeptide mapping and phosphoamino acid analysis. Phosphorylated proteins were digested with tosylphenylalanyl chloromethyl ketone-treated trypsin in $25 \mathrm{mM} N$-ethylmorpholine ( $\mathrm{pH}$ 8.0) as described previously (2). Phosphopeptide mapping was performed by two-dimensional separation on $100-\mu \mathrm{m}$ cellulose thin-layer plates (MacheryNagel). The first dimension was electrophoresis using $30 \%$ (vol/vol) formic acid at $500 \mathrm{~V}$ for $2 \mathrm{~h}$ at $4^{\circ} \mathrm{C}$. The second dimension was chromatography in the vertical direction using butan-1-ol-pyridine-acetic acid-water (75:50:15:60). The origin is located in the lower left corner of each peptide map. Phosphoamino acid analysis was performed by partial acid hydrolysis $\left(1 \mathrm{~h}\right.$ at $110^{\circ} \mathrm{C}$ in $\left.6 \mathrm{M} \mathrm{HCl}\right)$ and thin-layer electrophoresis as described previously (2).

Analysis of the level of GALA/Myc expression. Cells growing in 100-mm tissue culture dishes were washed once with phosphate-buffered saline and collected in $0.5 \mathrm{ml}$ of the same buffer. The cells were pelleted at $3,000 \times \mathrm{g}$ for $3 \mathrm{~min}$ at $4^{\circ} \mathrm{C}$ and resuspended in $0.5 \mathrm{ml}$ of $10 \mathrm{mM}$ HEPES, $\mathrm{pH} \mathrm{8.0-1.5}$ $\mathrm{mM} \mathrm{MgCl} 2-10 \mathrm{mM} \mathrm{KCl}-5 \mathrm{mM}$ dithiothreitol- $0.5 \%$ Nonidet P-40-1 mM phenylmethylsulfonyl fluoride-10 $\mu \mathrm{g}$ of leupeptin. After incubation for $1 \mathrm{~min}$ on ice, the lysate was centrifuged at $3,000 \times g$ for $3 \mathrm{~min}$. The pellet was then resuspended in $100 \mu \mathrm{l}$ of $20 \mathrm{mM}$ HEPES (pH 8.0)-25\% glycerol-0.42 M NaCl-0.2 mM EDTA-1 mM dithiothreitol-1 $\mathrm{mM}$ phenylmethylsulfonyl fluoride-10 $\mu \mathrm{g}$ of leupeptin per $\mathrm{ml}$. The extract was incubated on ice for $30 \mathrm{~min}$ and then centrifuged at $12,000 \times g$ for $10 \mathrm{~min}$ at $4^{\circ} \mathrm{C}$. The supernatant was collected as nuclear extract and stored at $-80^{\circ} \mathrm{C}$.

For COS cells, $20 \mu \mathrm{l}$ of nuclear extract was subjected to
SDS-PAGE and the resolved proteins were electrophoretically transferred onto a polyvinylidene difluoride membrane (Immobilon-P; Millipore Corp.). The membrane was then probed with a polyclonal rabbit anti-GALA antibody to detect the GALA/Myc fusion proteins, and the immune complexes were visualized by using ${ }^{125}$ I-protein $A$.

For CHO cells, the GALA/Myc proteins were first immunoprecipitated from $400 \mu$ l of nuclear extract by using a rabbit anti-GAL4 antibody and $20 \mu \mathrm{l}$ of protein A-Sepharose. The immunoprecipitate was subjected to SDS-PAGE, and the proteins were transferred onto an Immobilon-P membrane. The membrane was then probed with a polyclonal sheep anti-Myc antibody, and the immune complexes were visualized with rabbit anti-sheep immunoglobulin $\mathbf{G}$ coupled to horseradish peroxidase by the enhanced chemiluminescence detection method (Amersham International PLC).

\section{RESULTS}

Synchronization of the cell cycle. To investigate the cell cycle dependence of c-Myc function, we have employed cultures of synchronously growing cells. Inhibitors were used to induce growth arrest at specific stages of the cell cycle. Release of the cells from the growth arrest yielded cultures that maintained synchrony during the subsequent cell cycle. Several drugs that cause reversible growth arrest of cultured cells were used in this study. Hydroxyurea, an inhibitor of deoxyribonucleotide synthase (1), and aphidicolin, an inhibitor of DNA polymerase $\alpha(81)$, both inhibit DNA synthesis. These drugs were used to arrest cells at the $G_{1} / S$ boundary and early $S$ phase, respectively $(1,26,46,76$, $81,118)$. Hoechst 33372 , an inhibitor of DNA topoisomerase II, arrests cells in $G_{2}(85,113)$. These methods of growth arrest are reversible and yield synchronous cell populations.

Flow cytometry was used to determine cellular DNA content following propidium iodide staining (Fig. 1). $\left[{ }^{3} \mathrm{H}\right]$ thymidine incorporation was used as a measure of DNA synthesis (Fig. 2C). Following release of CHO cells from the growth arrest caused by hydroxyurea or aphidicolin, the cells were found to synchronously progress through the cell cycle. The synthesis of DNA, measured as $\left[{ }^{3} \mathrm{H}\right]$ thymidine incorporation, began within 15 min after the withdrawal of aphidicolin (data not shown) and $30 \mathrm{~min}$ following the withdrawal of hydroxyurea (Fig. 2C). A high level of $\left[{ }^{3} \mathrm{H}\right]$ thymidine incorporation was sustained for approximately $3 \mathrm{~h}$ and was markedly decreased by $6 \mathrm{~h}$ (Fig. 2C). Thus, DNA replication in $S$ phase starts shortly after the withdrawal of hydroxyurea or aphidicolin and ends at approximately $6 \mathrm{~h}$. Measurement of the average DNA content of the cells by flow cytometry confirmed this result (Fig. 1). After exit from $S$ phase, the cells traversed $G_{2}$ until approximately $9 \mathrm{~h}$ following the withdrawal of hydroxyurea when the cells reached the $\mathrm{G}_{2} / \mathrm{M}$ boundary. Mitotic cells were identified by microscopic analysis at 9 to $10 \mathrm{~h}$ following hydroxyurea withdrawal. Subsequent to mitosis, cells at the $G_{1}$ phase of the cell cycle were observed by flow cytometry (Fig. 1). For a small population of cells, exit from $\mathrm{G}_{2} / \mathbf{M}$ was delayed $(27,33)$, but the majority of the cells reached the $\mathrm{G}_{1} / \mathrm{S}$ boundary of the next cell cycle at approximately 18 to $20 \mathrm{~h}$ following the withdrawal of hydroxyurea (Fig. 1 and 2). Together, these data establish that a relatively synchronous population of $\mathrm{CHO}$ cells can be prepared for cell cycle analysis of the transactivation potential of c-Myc. A synchronous population of COS-7 cells was also obtained by the same procedures (data not shown). 

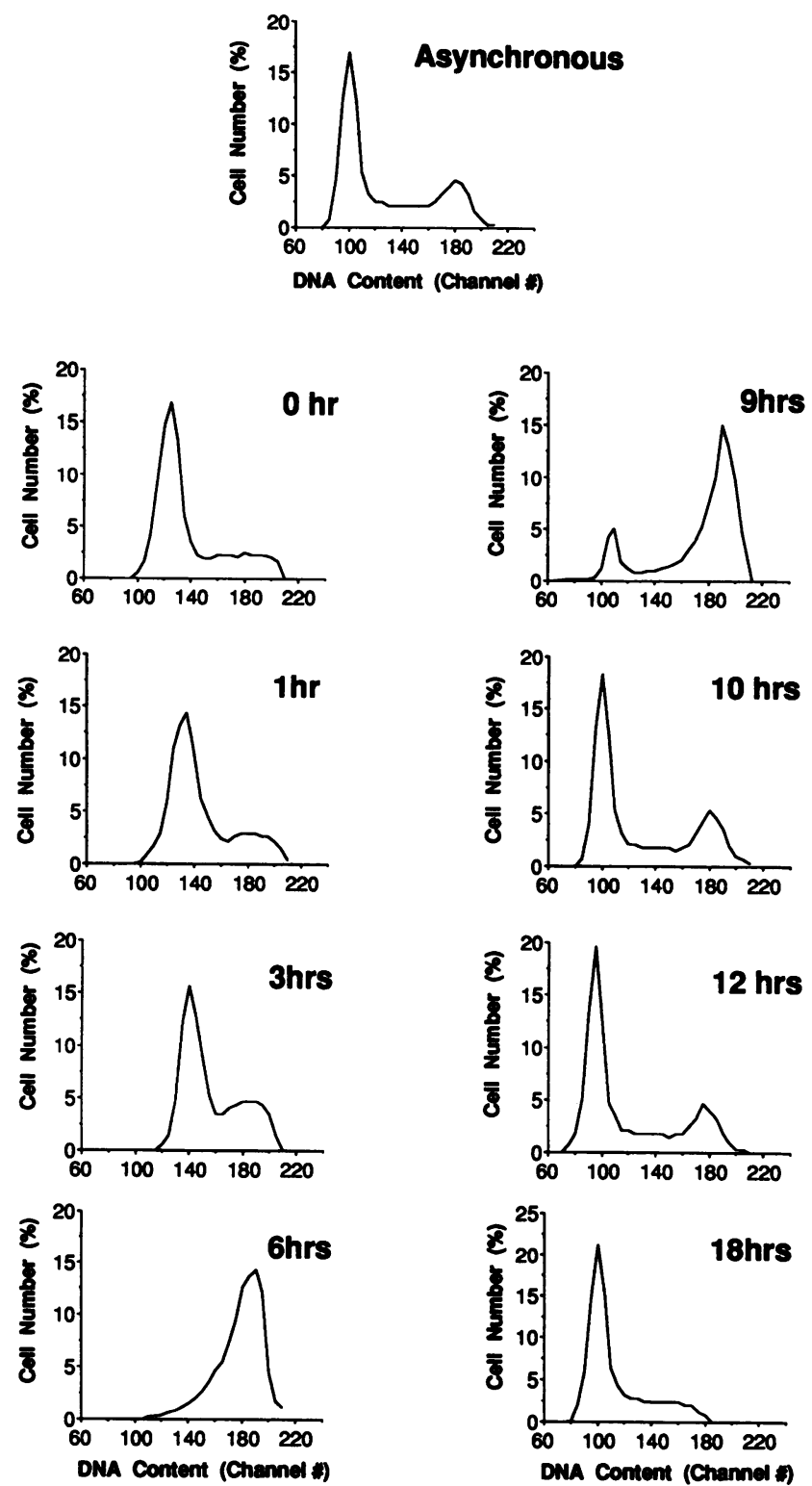

FIG. 1. Cell cycle analysis of the DNA content of synchronized CHO cells. CHO cells were released from hydroxyurea-induced growth arrest at the $G_{1} / S$ phase boundary and then harvested at defined times. The DNA content of the CHO cells was analyzed by flow cytometry and staining with propidium iodide. Histograms of the flow cytometric data obtained after different times of hydroxyurea withdrawal are presented.

Cell cycle-dependent expression of a reporter gene is conferred by the c-Myc DNA binding site CACGTG. A specific DNA binding site for c-Myc has been identified as the E-box sequence CACGTG $(13,48,63,80,90)$. Therefore, to investigate the level of c-Myc-dependent transactivation of gene expression, we constructed a reporter plasmid (pMyclElbLuc) that consists of a site for c-Myc binding (CACGTG) located adjacent to a minimal promoter (TATA) element and the firefly luciferase gene (Fig. 2A). A similar experimental strategy designed to monitor c-Myc function by using a reporter plasmid containing sites for c-Myc binding has been reported previously $(3,5,45,66)$. Cells transfected with the reporter plasmid pMyc1E1bLuc ex- pressed a high level of luciferase activity $\left(\sim 10^{5}\right.$ light units/ $10^{6}$ cells), and a three- to fivefold-increased level of luciferase activity was found when the cells were cotransfected with the c-Myc expression vector pM21. In contrast, cells transfected with a control reporter plasmid that lacked c-Myc binding sites (pMyc0E1bLuc) resulted in the expression of a low level of luciferase activity $\left(\sim 10^{4}\right.$ light units $/ 10^{6}$ cells) that was unaltered by cotransfection of the cells with the c-Myc expression vector. Together, these data demonstrate that the reporter plasmid pMyc1E1bLuc can be used as a probe to investigate the function of c-Myc (and other E-box binding proteins) expressed in cultured cells.

To assess the cell cycle dependence of transactivation of gene expression, we isolated stable $\mathrm{CHO}$ cell lines that were transfected with the c-Myc reporter plasmid pMyc1E1bLuc. Synchronous populations of cells were prepared by using the release from hydroxyurea-induced growth arrest at the $G_{1} / S$ phase boundary. The cells were then harvested at defined times as they traversed the cell cycle, and the luciferase activity present in the cell extracts was measured. It was observed that the luciferase activity exhibited a marked cell cycle dependence (Fig. 2A). The luciferase expression by $G_{1} / S$-arrested cells (zero hours following hydroxyurea withdrawal) was comparable to the activity of asynchronously growing cells. No marked change in luciferase activity was noted as the cells proceeded from $G_{1} / S$ through $S$ phase $(0$ to $5 \mathrm{~h}$ following hydroxyurea withdrawal). However, exit from $S$ phase (Fig. 1 and 2C) coincided with an increase in luciferase activity. During $G_{2}$ the luciferase activity continued to increase until a maximal level was reached at or near the $G_{2} / M$ boundary ( $9 \mathrm{~h}$ following hydroxyurea withdrawal). Mitosis was monitored by microscopic analysis of cell morphology (data not shown) and by analysis of cellular DNA content to observe the appearance of $G_{1}$ cells (Fig. 1). It was found that a marked decline in luciferase activity occurred as the cells progressed from the $G_{2} / M$ to the $G_{1}$ phase of the cell cycle (Fig. 2A). A lower level of luciferase activity persisted during $G_{1}$. However, the luciferase activity then decreased at the $G_{1} / S$ phase boundary (18 to $20 \mathrm{~h}$ following hydroxyurea withdrawal) coincident with increased $\left[{ }^{3} \mathrm{H}\right]$ thymidine incorporation (Fig. 2C). Significantly, a similar pattern of oscillating luciferase activity was noted as the cells passed through a second consecutive cell cycle (Fig. 2). However, the fold changes in activity were reduced compared with those in the first cycle, probably because of a decrease in cell synchrony. Similar changes in luciferase activity were observed when the cells were synchronized with aphidicolin or Hoechst 33372 (data not shown). Together, these data demonstrate that the luciferase expression by the c-Myc reporter plasmid pMyclElbLuc is cell cycle dependent with a marked increase during the $S-$ to $-G_{2} / M$ transition of the cell cycle.

Inceased function of the c-Myc transactivation domain during the $S-t_{0}-G_{2} / M$ transition of the cell cycle. The mechanistic basis for the cell cycle-dependent expression of the luciferase gene in cells transfected with the c-Myc reporter plasmid is unclear (Fig. 2A). Previous studies have established that c-Myc, Max, and c-Myc-Max heterodimers are expressed constitutively throughout the cell cycle $(16,28$, $49,61,94,112,116)$. Therefore, the observed cell cycledependent regulation (Fig. 2A) is not caused by changes in the level of expression of c-Myc-Max complexes $(16,61)$. However, several other regulatory mechanisms could account for the cell cycle-dependent transactivation potential of c-Myc. As an initial approach to resolve these possible mechanisms, we investigated whether alterations in the 
A
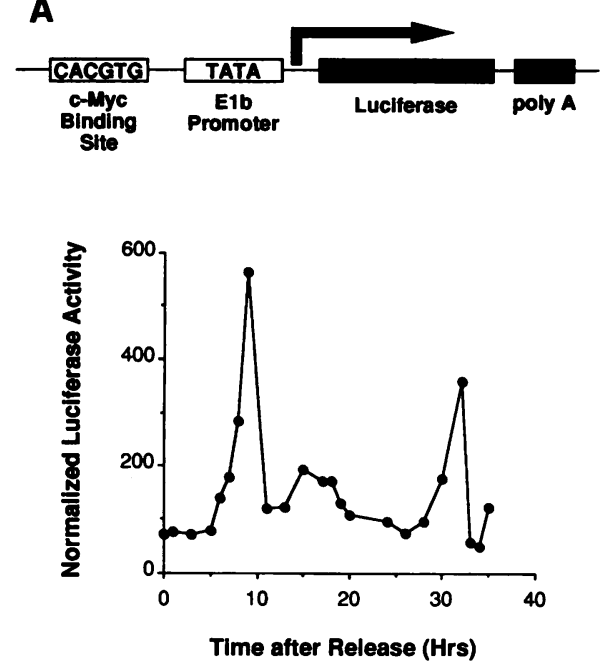

B

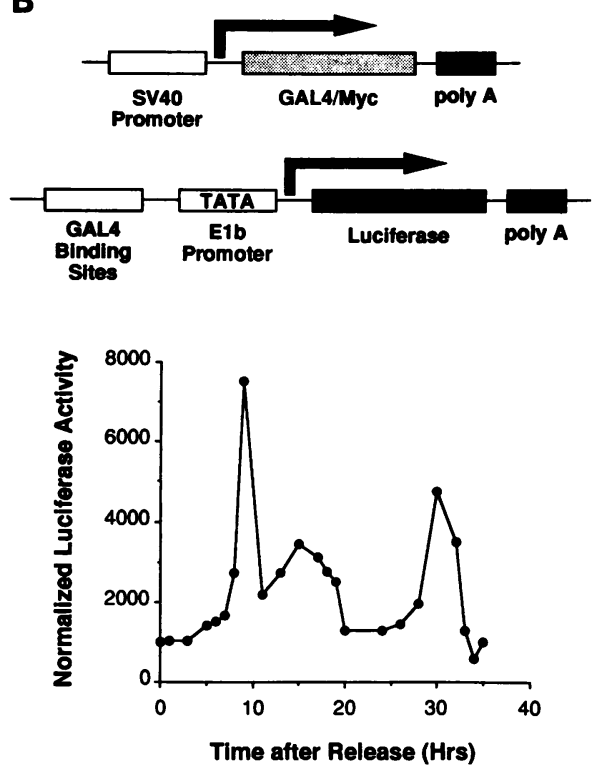

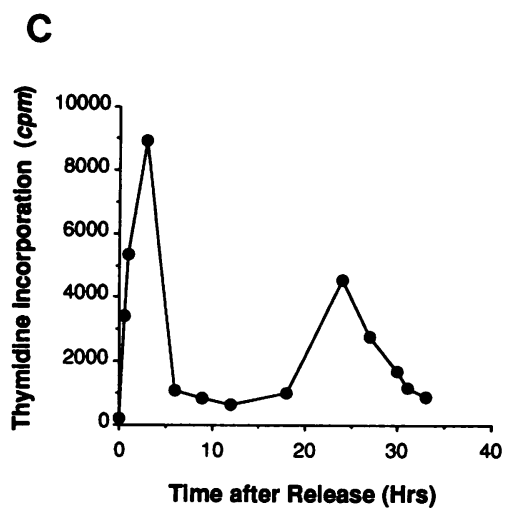

FIG. 2. Cell cycle-dependent transactivation of gene expression. CHO cells were released from hydroxyurea-induced growth arrest at the $\mathrm{G}_{1} / \mathrm{S}$ boundary and then harvested at defined times. Luciferase activities in cell extracts were measured as light units per milligram of protein and are presented as normalized luciferase activities. (A) Luciferase activity was measured in extracts prepared from cells stably transfected with a reporter plasmid containing a c-Myc binding site (pMyc1ElbLuc). (B) Luciferase activity was measured in extracts prepared from cells stably cotransfected with the GAL4/Myc activator plasmid (pGAL4/Myc) and the GAL4 reporter plasmid (pG5E1bLuc). (C) [ $\left.{ }^{3} \mathrm{H}\right]$ thymidine incorporation into DNA during a 30-min period was measured. Similar data were obtained in three separate experiments.

function of the c-Myc transactivation domain could account for the cell cycle-dependent regulation of the reporter gene expression. As the c-Myc protein is composed of several functional domains, the experimental strategy that we employed was to construct a fusion protein consisting of the $\mathrm{NH}_{2}$-terminal transactivation domain of c-Myc and the DNA binding domain of the yeast transcription factor GAL4 (59). This approach allows the direct analysis of the function of the c-Myc transactivation domain during the cell cycle.

We isolated stable CHO cells that expressed the GAL4/ Myc fusion protein together with a luciferase reporter plasmid (pG5E1bLuc) that contains sites for GAL4 binding (Fig. 2B). The cells were synchronized by using release from hydroxyurea-induced growth arrest, and extracts were prepared at different times during the subsequent cell cycle. Western blot analysis demonstrated that the level of expression of the GAL4/Myc fusion protein was not markedly altered as the cells progressed through the cell cycle (Fig. 3). In some experiments a small decrease in GAL/Myc expression was noted at 9 to $10 \mathrm{~h}$ following hydroxyurea withdrawal, but this decrease was not reproducibly observed (Fig. 3). Control experiments using the GAL 4 fusion protein expression vector (pSG424) confirmed the conclusion that the expression of the GAL4/Myc fusion protein was not cell cycle dependent (Fig. 4C). In contrast to the constitutive expression of GAL4/Myc (Fig. 3), the transactivation of luciferase expression by GAL4/Myc was observed to be cell cycle dependent (Fig. 2B). A marked increase in the transactivation of luciferase reporter gene expression by the GAL4/Myc fusion protein was observed as the cells progressed from the $S$ to the $G_{2} / M$ phase of the cell cycle (6 to $9 \mathrm{~h}$ following hydroxyurea withdrawal). A second smaller increase in luciferase activity was noted during the $G_{1}$ phase of the cell cycle (10 to $18 \mathrm{~h}$ following hydroxyurea withdrawal). Similar cell cycle-dependent changes in luciferase activ- ity were noted when the cells were synchronized with aphidicolin or with Hoechst 33372 (data not shown).

Control experiments demonstrated that the GAL4 reporter plasmid (pG5E1bLuc) exhibited no cell cycle-regulated expression in the absence of the GAL4/Myc fusion protein (Fig. 4B). Therefore, we conclude that the transac-

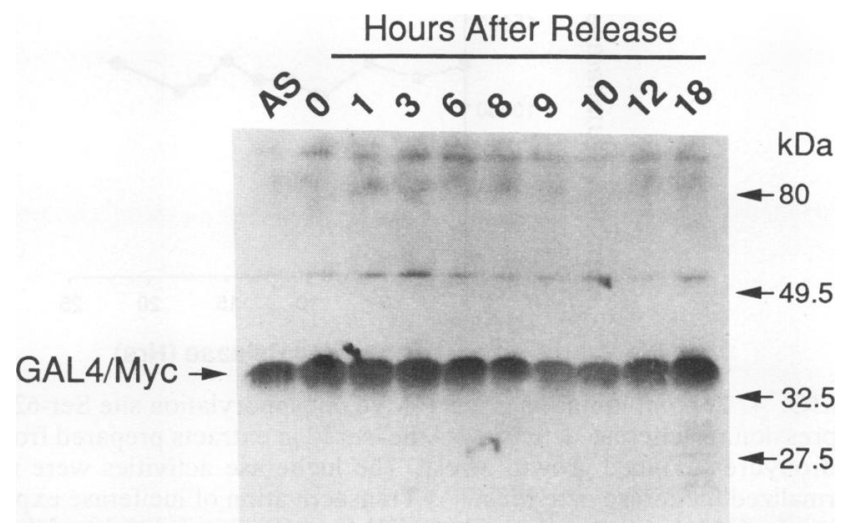

FIG. 3. Analysis of GAL4/Myc fusion protein expression during the cell cycle. Stable CHO cell transformants that express the GALA/Myc fusion protein were released from hydroxyurea-induced growth arrest at the $G_{1} / S$ boundary and then harvested at defined times. Asynchronously (AS) growing cells were also harvested for analysis of GALA/Myc fusion protein expression. Nuclear extracts were prepared, and the GAL4/Myc proteins were isolated by immunoprecipitation with an anti-GALA antibody. The level of the GAL4/Myc fusion protein was examined by Western blot analysis using an anti-Myc antibody and enhanced chemiluminescence detection system. Similar results were obtained in three separate experiments. 

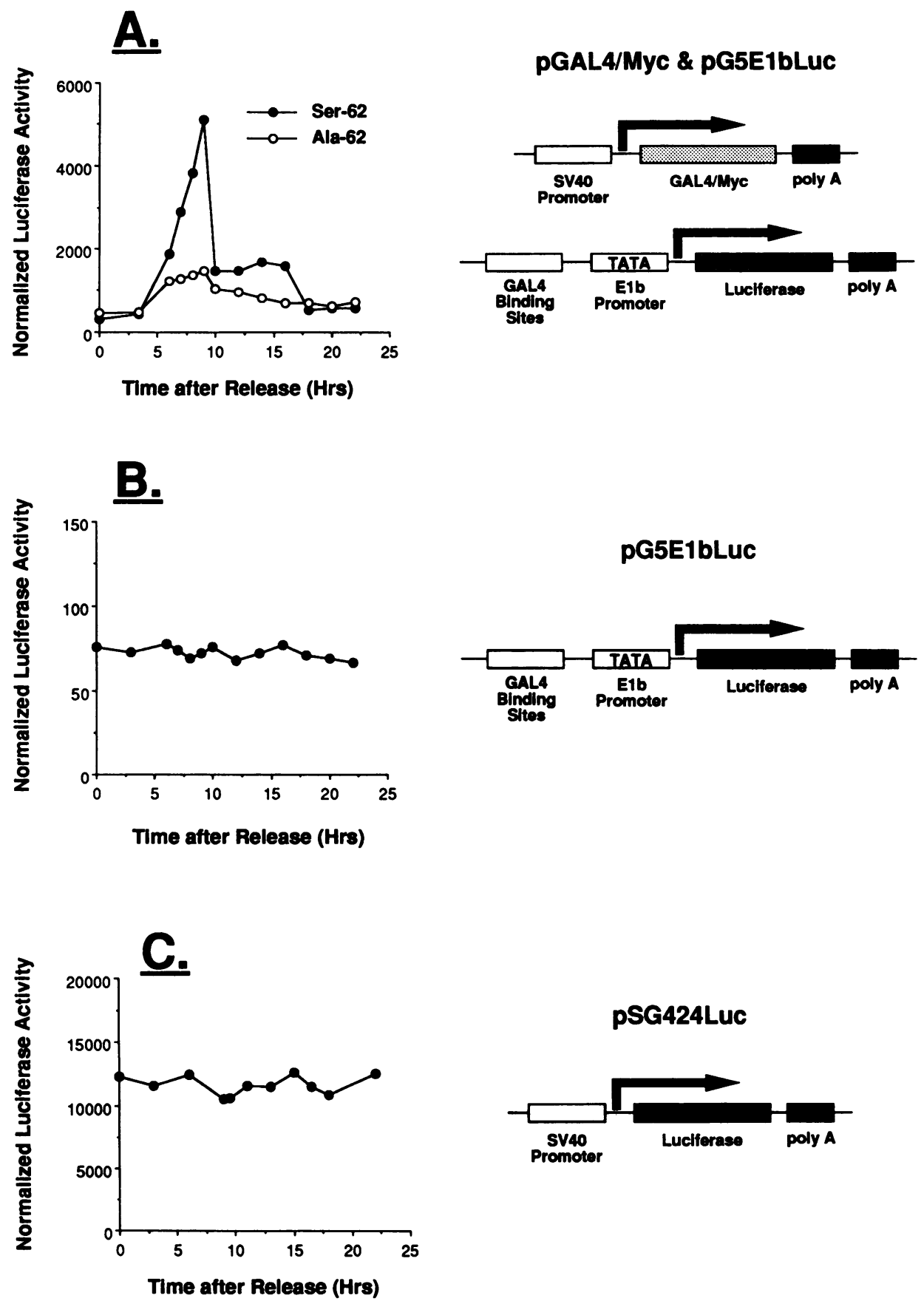

FIG. 4. A point mutation at the c-Myc phosphorylation site Ser-62 causes decreased cell cycle-dependent transactivation of reporter gene expression. Luciferase activity was measured in extracts prepared from stably transfected CHO cells at different times following release from hydroxyurea-induced growth arrest. The luciferase activities were measured as light units per milligram of protein and are presented as normalized luciferase activities. (A) Transactivation of luciferase expression by GAL4/Myc (O) and GAL4/[Ala $\left.{ }^{62}\right] \mathrm{Myc}(\Theta)$ was examined by using the GAL4 reporter plasmid pG5E1bLuc. (B) Basal activity of the GAL4 reporter plasmid (pG5E1bLuc) in the absence of the GAL4/Myc fusion protein. (C) The expression by the GAL4 fusion protein vector (pSG424) was examined by using the plasmid pSG424-Luc. Similar data were obtained in three separate experiments.

tivation potential of the GAL4/Myc fusion protein is regulated during the cell cycle. Significantly, the oscillation of transactivation potential observed for the GALA/Myc fusion protein (Fig. 2B) was similar to cell cycle-dependent changes in luciferase activity detected in cells transfected with the c-Myc reporter plasmid (Fig. 2A). Together, these data suggest that the regulation of the c-Myc reporter plasmid can be accounted for by cell cycle-dependent changes in the function of the c-Myc transactivation domain. Furthermore, these data establish that the observed cell cycle regulation of transactivation potential of c-Myc is independent of changes in the function of Max, Mad, and Mxil. 

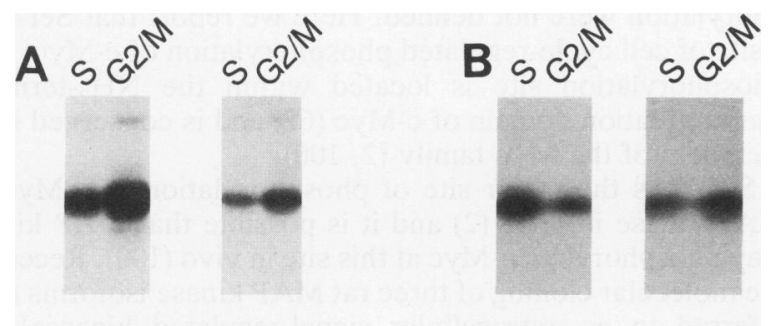

Ser-62 Ala-62

\section{Ser-62 Ala-62}

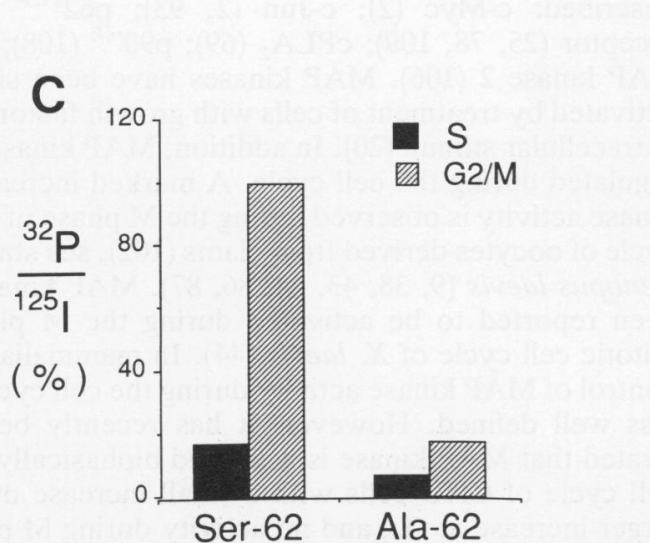

FIG. 5. Increased phosphorylation of the c-Myc transactivation domain at the $G_{2} / M$ phase of the cell cycle. COS-7 cells were transfected with $10 \mu \mathrm{g}$ of the GAL4/Myc expression plasmid (pGAL4/Myc or pGAL4/[Ala $\left.{ }^{62}\right] \mathrm{Myc}$ ). The cells were released from hydroxyurea-induced growth arrest for $2 \mathrm{~h}$ (S phase) or for $\mathbf{8 h}\left(\mathrm{G}_{2} / \mathrm{M}\right.$ phase). (A) Cells were labeled by incubation at $37^{\circ} \mathrm{C}$ for $4 \mathrm{~h}$ with 2 $\mathrm{mCi}$ of $\left[{ }^{32} \mathrm{P}\right]$ phosphate per $\mathrm{ml}$. The GAL4/Myc fusion proteins were immunoprecipitated with a rabbit anti-GALA antibody and analyzed by SDS-PAGE and autoradiography. (B) Immunoblot analysis of the cell lysates was used to measure the level of expression of the GALA/Myc fusion proteins. The blot was probed with an anti-GALA antibody, and the Myc fusion proteins were visualized with ${ }^{125} \mathrm{I}$ protein A and autoradiography. (C) The radioactivity was quantitated with a Phosphorimager and ImageQuant software (Molecular Dynamics Inc.) and the ${ }^{32} \mathrm{P} /{ }^{125} \mathrm{I}$ ratio for the GAL4/Myc fusion proteins was calculated. Normalized values for the ${ }^{32} \mathrm{P} /{ }^{125} \mathrm{I}$ ratio are presented. Similar results were obtained in three separate experiments.

A point mutation at the phosphorylation site Ser-62 suppresses the cell cycle-dependent regulation of the c-Myc transactivation domain. In previous studies it has been established that phosphorylation represents one mechanism of regulation of the c-Myc transactivation domain $(45,54,55,99,100)$ and that the c-Myc protein is hyperphosphorylated at the $\mathrm{G}_{2} / \mathrm{M}$ phase of the cell cycle (71). We therefore tested the hypothesis that phosphorylation is a mechanism that can account for the cell cycle regulation of the c-Myc transactivation domain. The phosphorylation state of the GAL4/Myc fusion protein was examined at the two stages of the cell cycle where the highest $\left(\mathrm{G}_{2} / \mathrm{M}\right.$ phase) and lowest (S phase) levels of transactivation potential were observed (Fig. 2B). In experiments using synchronized COS-7 cells, it was found that there was a marked increase in both the transactivation potential (data not shown) and the state of phosphorylation of the GAL4/Myc fusion protein at $G_{2} / M$ compared with that at $\mathrm{S}$ phase (Fig. 5). Phosphoamino acid analysis revealed an

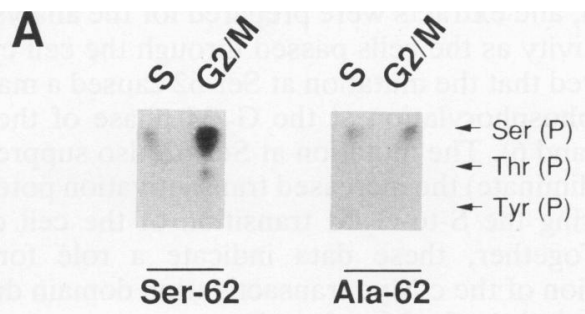

B s

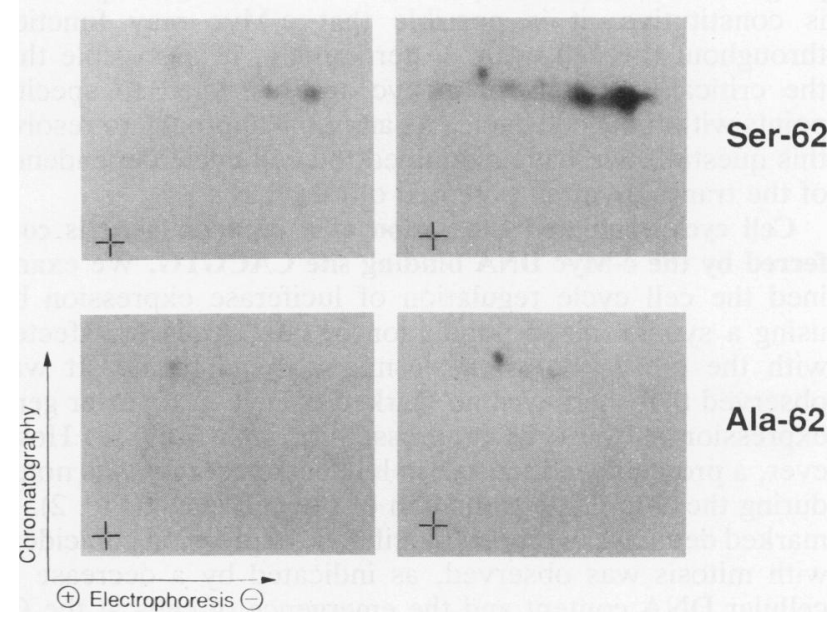

FIG. 6. Characterization of the cell cycle-dependent phosphorylation of the c-Myc transactivation domain by phosphoamino acid analysis and phosphopeptide mapping. The GAL4/Myc fusion proteins (Fig. 5) were analyzed by $\left[{ }^{32} \mathrm{P}\right]$ phosphoamino acid analysis (panel A) and by tryptic [ ${ }^{32}$ P]phosphopeptide mapping (panel B). The origin is marked with a cross at the lower left corner of each peptide map, and the electrophoretic (cathode at right) and chromatographic dimensions are illustrated. The exposure times for autoradiography were 5 days (panel A) and 7 days (panel B) at $-80^{\circ} \mathrm{C}$ using Kodak X-OMAT AR film and a Dupont Lightning Plus enhancing screen.

increase in $\left[{ }^{32} \mathrm{P}\right]$ phosphoserine and a small increase in $\left.{ }^{32} \mathrm{P}\right]$ phosphothreonine (Fig. 6A). Tryptic phosphopeptide mapping demonstrated that the increased phosphorylation can be accounted for by a change in the level of a tryptic $\left[{ }^{32} \mathrm{P}\right]$ phosphopeptide doublet (Fig. 6B). This phosphopeptide doublet has previously been demonstrated to be due to the presence of both limit and partial tryptic peptides corresponding to the region surrounding Ser-62 (2). Significantly, the replacement of Ser-62 with Ala resulted in the loss of this tryptic phosphopeptide doublet (Fig. 6B). Three additional minor tryptic $\left[{ }^{32} \mathrm{P}\right]$ phosphopeptides were observed to be increased in maps obtained from cells at $\mathrm{G}_{2} / \mathrm{M}$ compared with cells in $S$ phase (Fig. 6B). Together, these data reveal a complex pattern of cell cycle-dependent phosphorylation of the c-Myc transactivation domain that includes (but is not limited to) phosphorylation at Ser-62.

To examine the role of phosphorylation of the c-Myc transactivation domain at Ser-62, the effect of mutation at this site was investigated. We isolated $\mathrm{CHO}$ cells that stably expressed the $\mathrm{GAL} 4 /\left[\mathrm{Ala}^{62}\right] \mathrm{Myc}$ fusion protein together with the pG5E1bLuc reporter plasmid. The cells were then 
synchronized, and extracts were prepared for the analysis of luciferase activity as the cells passed through the cell cycle. It was observed that the mutation at Ser-62 caused a marked decrease in phosphorylation at the $G_{2} / M$ phase of the cell cycle (Fig. 5 and 6). The mutation at Ser-62 also suppressed (but did not eliminate) the increased transactivation potential observed during the $S-$ to $\mathrm{G}_{2} / \mathrm{M}$ transition of the cell cycle (Fig. 4A). Together, these data indicate a role for the phosphorylation of the c-Myc transactivation domain during cell cycle regulation of c-Myc function.

\section{DISCUSSION}

c-Myc function is thought to be required for cell cycle progression and cellular proliferation. As c-Myc expression is constitutive, it is possible that $\mathrm{c}-\mathrm{Myc}$ may function throughout the cell cycle. Alternatively, it is possible that the critical functions of c-Myc are restricted to specific points within the cell cycle. As an initial approach to resolve this question, we have examined the cell cycle dependence of the transactivation potential of c-Myc.

Cell cycle-regulated expression of a reporter gene is conferred by the c-Myc DNA binding site CACGTG. We examined the cell cycle regulation of luciferase expression by using a synchronized population of CHO cells transfected with the c-Myc reporter plasmid pMyc1ElbLuc. It was observed that there was no marked change in reporter gene expression as the cells progressed through $S$ phase. However, a pronounced increase in luciferase activity was noted during the S-to- $\mathrm{G}_{2} / \mathrm{M}$ transition of the cell cycle (Fig. 2). A marked decrease in reporter luciferase expression coincident with mitosis was observed, as indicated by a decrease in cellular DNA content and the emergence of cells at the $G_{1}$ phase of the cell cycle. Following this, the reporter luciferase activity remained moderately high during $G_{1}$ until the $G_{1} / S$ boundary, when a decline in activity was observed. The luciferase expression by $\mathrm{CHO}$ cells transfected with the c-Myc reporter plasmid therefore exhibits biphasic cell cycle regulation with a small increase during $G_{1}$ and a marked increase during $\mathrm{G}_{2}$ (Fig. 2A).

We tested the hypothesis that the activity of the c-Myc transactivation domain contributes to the cell cycle regulation of the expression of luciferase activity observed in experiments using $\mathrm{CHO}$ cells transfected with the c-Myc reporter plasmid pMyc1E1bLuc (Fig. 2). The experimental approach that we employed was to construct a hybrid transcription factor consisting of the transactivation domain of c-Myc fused to the DNA binding domain of the yeast transcription factor GALA (59). Using this fusion protein strategy, we determined that the transactivation of gene expression mediated by this domain of c-Myc is cell cycle regulated with a marked increase in activity during the S-to- $G_{2} / M$ transition. Thus, changes in the function of the c-Myc transactivation domain can account, in part, for the cell cycle-dependent regulation of the c-Myc reporter plasmid (Fig. 2).

Cell cycle-dependent phosphorylation of the c-Myc transactivation domain at Ser-62. Protein phosphorylation offers many useful features as a regulatory mechanism that permits the regulation of transcription factors and thereby gene expression $(54,55)$. Indeed, protein phosphorylation represents an important mechanism of regulation of the mammalian cell cycle (77). Recently, Lüscher and Eisenman (71) have presented evidence demonstrating that the phosphorylation state of c-Myc is regulated during the cell cycle, although the site(s) and functional significance of the phos- phorylation were not defined. Here we report that Ser-62 is a site of cell cycle-regulated phosphorylation of c-Myc. This phosphorylation site is located within the $\mathbf{N H}_{2}$-terminal transactivation domain of c-Myc (62) and is conserved in all members of the Myc family $(2,100)$.

Ser-62 is the major site of phosphorylation of c-Myc by MAP kinase in vitro (2) and it is possible that MAP kinase may phosphorylate c-Myc at this site in vivo (100). Recently, the molecular cloning of three rat MAP kinase isoforms (also referred to as extracellular signal-regulated kinases) has been reported by Boulton et al. $(17,18)$. A consensus sequence for the phosphorylation of substrates has been defined $(2,19,41)$ and several protein substrates have been described: c-Myc (2); c-Jun (2, 93); p62 ${ }^{\text {TCF }}$ (40); EGF receptor $(25,78,109)$; CPLA $_{2}$ (69); p90'sk (108); and MAPKAP kinase 2 (106). MAP kinases have been shown to be activated by treatment of cells with growth factors and other extracellular stimuli (20). In addition, MAP kinase activity is regulated during the cell cycle. A marked increase in MAP kinase activity is observed during the $M$ phase of the meiotic cycle of oocytes derived from clams (102), sea stars (98), and Xenopus laevis $(9,38,43,44,86,87)$. MAP kinase has also been reported to be activated during the $M$ phase of the mitotic cell cycle of $X$. laevis (44). In mammalian cells, the control of MAP kinase activity during the cell cycle has been less well defined. However, it has recently been demonstrated that MAP kinase is activated biphasically during the cell cycle of $\mathrm{CHO}$ cells with a small increase during $\mathrm{G}_{1}$, a larger increase at $G_{2}$, and no activity during $M$ phase (110). Significantly, this pattern of MAP kinase activation in CHO cells is similar to the observed cell cycle regulation of the c-Myc transactivation domain (Fig. 2A). Thus, MAP kinase could account for the cell cycle regulation of $\mathrm{c}-\mathrm{Myc}$ phosphorylation in vivo. Glycogen synthase kinase-3 may also contribute to the phosphorylation of c-Myc at Ser-62 (97). However, as Ser-62 is a substrate for the cell cycle-regulated p34 ${ }^{c d c 2}$ protein kinase (99), it is likely that there is a prominent role for one or more cyclin-dependent protein kinases in the control of c-Myc phosphorylation. In addition, it is possible that there may also be a role for changes in protein phosphatase activity. Thus, the regulation of c-Myc phosphorylation at Ser-62 is likely to be complex and probably involves more than one kinase or phosphatase acting at different stages of the cell cycle.

Role of cell cycle-regulated phosphorylation of the c-Myc transactivation domain at Ser-62. To examine the significance of the cell cycle-dependent phosphorylation of the c-Myc transactivation domain, we investigated the effect of the replacement of Ser-62 with Ala. This mutation suppressed the cell cycle regulation of both the activity and phosphorylation state of the c-Myc transactivation domain (Fig. 4 and 5). The inhibited activity of the mutated Ala-62 c-Myc transactivation domain could be mediated by nonspecific structural alterations that may compromise the function of the transactivation domain under both basal and activated conditions. However, we have previously demonstrated that phosphorylation at Ser-62 positively regulates the activity of the c-Myc transactivation domain $(45,99,100)$. Together, these considerations indicate that the phosphorylation site Ser-62 accounts, in part, for the cell cycle regulation of c-Myc function.

Although the replacement of Ser-62 with Ala greatly diminished the increase in transactivation observed during the $G_{2}$ phase of the cell cycle, this mutation did not completely block the cell cycle regulation of reporter gene expression (Fig. 4). This result indicates that mechanisms in 
addition to phosphorylation at Ser-62 must also contribute to the cell cycle regulation of c-Myc function. Phosphopeptide mapping demonstrates that while Ser-62 represents a major site of cell cycle-regulated phosphorylation, additional sites of c-Myc phosphorylation also exist (Fig. 6). It is therefore possible that the phosphorylation of c-Myc at one or more of these additional sites may also contribute to the cell cycle regulation of c-Myc activity. A regulatory mechanism that is independent of c-Myc phosphorylation could also contribute to the changes in transactivation potential observed during the cell cycle. One plausible mechanism is the regulation of Max (10), although this would not account for cell cycledependent transactivation caused by the GALA/Myc fusion protein (Fig. 2). Alternatively, it is possible that an interaction of the c-Myc transactivation domain with a heterologous protein is required for cell cycle regulation. Indeed, c-Myc is known to bind to the nuclear matrix $(36,115)$. Furthermore, in vitro studies have shown that the c-Myc transactivation domain binds to the retinoblastoma protein, $\mathrm{Rb}(96)$. It is therefore possible that an $\mathrm{Rb}$-like protein could contribute to the cell cycle regulation of c-Myc function in vivo $(29,57$, 117).

Role of $\mathrm{c}-\mathrm{Myc}$ in the S-to- $\mathrm{G}_{2} / \mathrm{M}$ transition of the cell cycle. It is known that nuclear proto-oncogenes can modulate the expression of critical genes involved in cell cycle progression $(47,53)$. Although there is strong evidence to suggest a role for c-Myc in the regulation of the cell cycle, the molecular mechanism of c-Myc action and the stage(s) of the cell cycle influenced by c-Myc are not well understood. In previous studies, a role for c-Myc during $G_{1}$ or at the $G_{1} / S$ boundary has been indicated $(6,34,35,42,50,51,58,65,83$, 84). The observation of elevated transactivation of the c-Myc reporter plasmid during $G_{1}$ (Fig. 2) is consistent with the hypothesis that c-Myc functions during the $G_{1}$ phase of the cell cycle. However, the major peak of transactivation of the c-Myc reporter plasmid was found during the S-to- $G_{2} / M$ transition (Fig. 2) indicating that c-Myc may also have an important function during the $G_{2}$ phase of the cell cycle.

One of the functions of $G_{2}$ is to ensure that $S$ phase ends before cell division begins, thereby guaranteeing an obligatory temporal relationship between DNA replication and mitosis (77). On the basis of this information, we propose a role for c-Myc in the regulation of the expression of one or more genes that are required for the cell to progress from $S$ phase to mitosis. Evidence that supports this hypothesis has recently been reported by Shibuya et al. (103) in experiments designed to characterize a defect in the EGF-stimulated growth of BAF-BO3 cells. Treatment of these cells with EGF results in entry into $S$ phase, but further progression through the cell cycle is blocked. Significantly, this defect can be corrected by the ectopic expression of the c-myc gene, indicating that $\mathrm{c}-\mathrm{Myc}$ is required for progression through $G_{2}(103)$. These observations, together with the results of the present study, strongly support the contention that c-Myc may have an important function during the $G_{2}$ phase of the cell cycle.

\section{ACKNOWLEDGMENTS}

We thank M. Ptashne, C. V. Dang, and C. W. Woon for providing reagents. The secretarial assistance of Margaret Shepard is greatly appreciated.

R. J. Davis is an Investigator of the Howard Hughes Medical Institute. This work was supported by grants (CA58396 and GM37845) from the National Institutes of Health.

\section{REFERENCES}

1. Adams, R. L. P., and J. G. Lindsay. 1967. Hydroxyurea: reversal of inhibition and use as a cell-synchronizing agent. J. Biol. Chem. 242:1314-1317.

2. Alvarez, E., I. C. Northwood, F. A. Gonzalez, D. A. Latour, A. Seth, C. Abate, T. Curran, and R. J. Davis. 1991. Pro-Leu-Ser/ Thr-Pro is a consensus primary sequence for substrate protein phosphorylation: characterization of the phosphorylation of $c$-myc and $c$-jun proteins by an epidermal growth factor receptor threonine 669 protein kinase. J. Biol. Chem. 266:1527715285.

3. Amati, B., M. W. Brooks, N. Levy, T. D. Littlewood, G. I. Evan, and H. Land. 1993. Oncogenic activity of the c-Myc protein requires dimerization with Max. Cell 72:233-245.

4. Amati, B., S. Dalton, M. W. Brooks, T. D. Littlewood, G. I. Evan, and H. Land. 1992. Transcriptional activation by the human c-Myc oncoprotein in yeast requires interaction with Max. Nature (London) 359:423-426.

5. Amin, C., A. J. Wagner, and N. Hay. 1993. Sequence-specific transcriptional activation by Myc and repression by Max. Mol. Cell. Biol. 13:383-390.

6. Armelin, H. A., M. C. S. Armelin, K. Kelly, T. Stewart, P. Leder, B. H. Cochran, and C. D. Stiles. 1984. Functional role for $c-m y c$ in mitogenic response to platelet derived growth factor. Nature (London) 310:655-660.

7. Ayer, D. E., L. Kretzner, and R. N. Eisenman. 1993. Mad: a heterodimeric partner for Max that antagonizes Myc transcriptional activity. Cell 72:211-222.

8. Bar-Ner, M., L. T. Messing, C. M. Cultraro, M. J. Birrer, and S. Segal. 1992. Regions within the c-Myc protein that are necessary for transformation are also required for inhibition of differentiation of murine erythroleukemia cells. Cell Growth Differ. 3:183-190.

9. Barrett, C. B., E. Erikson, and J. L. Maller. 1992. A purified S6 kinase kinase from Xenopus eggs activates S6 kinase II and autophosphorylates on serine, threonine, and tyrosine residues. J. Biol. Chem. 267:4408-4415.

10. Berberich, S. J., and M. D. Cole. 1992. Casein kinase II inhibits the DNA-binding activity of Max homodimers but not Myc/ Max heterodimers. Genes Dev. 6:166-176.

11. Birrer, M. J., L. Raveh, H. Dosaka, and S. Segal. 1989. A transfected L-myc gene can substitute for c-myc in blocking murine erythroleukemia differentiation. Mol. Cell. Biol. 9:2734-2737.

12. Bissonnette, R. P., F. Echeverri, A. Mahboubi, and D. R. Green. 1992. Apoptic cell death induced by $c-m y c$ is inhibited by $b c l-2$. Nature (London) 359:552-556.

13. Blackwell, T. K., L. Kretzner, E. M. Blackwood, R. N. Eisenman, and H. Weintraub. 1990. Sequence-specific DNA binding by the c-Myc protein. Science 250:1149-1151.

14. Blackwood, E. M., and R. N. Eisenman. 1991. Max: A helixloop-helix zipper protein that forms a sequence-specific DNAbinding complex with Myc. Science 251:1211-1217.

15. Blackwood, E. M., L. Kretzner, and R. N. Eisenman. 1992. Myc and Max function as a nucleoprotein complex. Curr. Opin. Genet. Dev. 2:227-235.

16. Blackwood, E. M., B. Lüscher, and R. N. Eisenman. 1992. Myc and Max associate in vivo. Genes Dev. 6:71-80.

17. Boulton, T. G., S. H. Nye, D. J. Robbins, N. Y. Ip, E. Radziejewska, S. D. Morgenbesser, R. A. DePinho, N. Panayotatos, M. H. Cobb, and G. D. Yancopoulos. 1991. ERKs: a family of protein-serine/threonine kinases that are activated and tyrosine phosphorylated in response to insulin and NGF. Cell 68:663-675.

18. Boulton, T. G., G. D. Yancopoulos, J. S. Gregory, C. Slaughter, C. Moomaco, J. Hsu, and M. H. Cobb. 1990. An insulin stimulated protein kinase similar to yeast kinases involved in cell cycle control. Science 249:64-67.

19. Clark-Lewis, I., J. S. Sanghera, and S. L. Pelech. 1991. Definition of a consensus sequence for peptide substrate recognition by $\mathrm{p} 44^{m p k}$, the meiosis-activated myelin basic protein kinase. J. Biol. Chem. 266:15180-15184.

20. Cobb, M. H., T. G. Boulton, and D. J. Robbins. 1991. Extra- 
cellular signal-regulated kinases: ERKs in progress. Cell Regul. 2:965-978.

21. Coffey, R. J., Jr., C. C. Bascom, N. J. Sipes, R. Graves-Deal, B. E. Weissman, and H. L. Moses. 1988. Selective inhibition of growth-related gene expression in murine keratinocytes by transforming growth factor beta. Mol. Cell. Biol. 8:3088-3093.

22. Cole, M. D. 1986. The myc oncogene: its role in transformation and differentiation. Annu. Rev. Genet. 20:361-384.

23. Cole, M. D. 1991. Myc meets its Max. Cell 65:715-716.

24. Copolla, J. S., and M. D. Cole. 1986. Constitutive $c$-myc oncogene expression blocks mouse erythroleukemia cell differentiation but not commitment. Nature (London) 320:760763.

25. Countaway, J. L., I. C. Northwood, and R. J. Davis. 1989. Mechanism of phosphorylation of the epidermal growth factor receptor at threonine 669. J. Biol. Chem. 264:10828-10835.

26. Coyle, M. B., and B. Strauss. 1970. Cell killing and the accumulation of breaks in the DNA of HEp-2 cells incubated in the presence of hydroxyurea. Cancer Res. 30:2314-2319.

27. Dalton, S. 1992. Cell cycle regulation of the human $c d c 2$ gene. EMBO J. 11:1797-1804.

28. Dean, M., R. A. Levine, W. Ran, M. S. Kindy, G. E. Sonnenshein, and J. Campisi. 1986. Regulation of $c$-myc transcription and mRNA abundance by serum growth factors and cell contact. J. Biol. Chem. 261:9161-9166.

29. DeCaprio, J. A., J. W. Ludlow, D. Lynch, Y. Furukawa, J. Griffen, H. Piwnica-Worms, C.-H. Huang, and D. M. Livingston. 1989. The product of the retinoblastoma susceptibility gene has properties of a cell cycle regulatory element. Cell 58:1085-1095.

30. Dmitrovsky, E., W. M. Kuehl, G. F. Hollis, I. R. Kirsch, T. P. Bender, and S. Segal. 1986. Expression of a transfected human $c$-myc oncogene inhibits differentiation of a mouse erythroleukaemia cell line. Nature (London) 322:748-750.

31. Dotto, G. P., M. Z. Gilman, M. Maruyama, and R. A. Weinberg. 1986. $c$-myc and $c$-fos expression in differentiating mouse primary keratinocytes. EMBO J. 5:2853-2857.

32. Downs, K. M., G. R. Martin, and J. M. Bishop. 1989. Contrasting patterns of myc and $\mathrm{N}$-myc expression during gastrulation of the mouse embryo. Genes Dev. 3:860-869.

33. Dulic, V., E. Lees, and S. I. Reed. 1992. Association of human cyclin $\mathbf{E}$ with a periodic G1-S phase protein kinase. Science 257:1958-1961.

34. Eilers, M., D. Picard, K. R. Yamamoto, and J. M. Bishop. 1989. Chimaeras of myc oncoprotein and steroid receptors cause hormone-dependent transformation of cells. Nature (London) 340:66-68.

35. Eilers, M., S. Schrim, and J. M. Bishop. 1991. The Myc protein activates transcription of the $\alpha$-prothymosin gene. EMBO J. 10:133-141.

36. Eisenman, R. N., C. Y. Tachibana, H. D. Abrams, and S. R. Hann. 1985. v-myc- and c-myc-encoded proteins are associated with the nuclear matrix. Mol. Cell. Biol. 5:114-126.

37. Evan, G. I., A. H. Wyllie, C. S. Gilbert, T. D. Littlewood, H. Land, M. Brooks, C. M. Waters, L. Z. Penn, and D. C. Hancock. 1992. Induction of apoptosis in fibroblasts by c-myc protein. Cell 69:119-128.

38. Ferrell, J. E., M. Wu, J. C. Gerhart, and G. S. Martin. 1991. Cell cycle tyrosine phosphorylation of $\mathrm{p}^{\text {cdc }}$ and a MAPkinase homolog in Xenopus oocytes and eggs. Mol. Cell. Biol. 11:1965-1971.

39. Freytag, S. O., C. V. Dang, and W. M. F. Lee. 1990. Definition of the activities and properties of c-myc required to inhibit cell differentiation. Cell Growth Differ. 1:339-343.

40. Gille, H., A. D. Sharrocks, and P. E. Shaw. 1992. Phosphorylation of transcription factor $\mathrm{p} 62^{T C F}$ by MAP kinase stimulates ternary complex formation at $c$-fos promoter. Nature (London) 358:414-417.

41. Gonzalez, F. A., D. L. Raden, and R. J. Davis. 1991. Identification of substrate recognition determinants for human ERK1 and ERK2 protein kinases. J. Biol. Chem. 266:22159-22163.

42. Goodrich, D. W., and W.-H. Lee. 1992. Abrogation by c-myc of G1 phase arrest induced by RB protein but not by p53. Nature
(London) 360:177-179.

43. Gotoh, Y., K. Moriyama, S. Matsuda, E. Okamura, T. Kishimoto, H. Kawasaki, K. Suzuki, and E. Nishida. 1991. Xenopus $M$ phase MAP kinase: isolation of its CDNA and activation by MPF. EMBO J. 10:2661-2668.

44. Gotoh, Y., E. Nishide, S. Matsuda, N. Shiina, H. Kosako, K. Shiokawa, T. Akiyama, K. Ohta, and H. Sakai. 1991. Purification and properties of an M-phase activated MAP kinase from Xenopus oocytes and its effects on microtubule dynamics in vitro. Nature (London) 349:251-254.

45. Gupta, S., A. Seth, and R. J. Davis. 1993. Transactivation of gene expression by Myc is inhibited by mutation at the phosphorylation sites Thr-58 and Ser-62. Proc. Natl. Acad. Sci. USA 90:3216-3220.

46. Gurley, L. R., R. A. Walters, and R. A. Tobey. 1975. Sequential phosphorylation of histone subfractions in the chinese hamster cell cycle. J. Biol. Chem. 250:3936-3944.

47. Gutman, A., and B. Wasylyk. 1991. Nuclear targets for transcription regulation by oncogenes. Trends Genet. 7:49-54.

48. Halazonetis, T. D., and A. N. Kandil. 1991. Determination of the c-Myc DNA binding site. Proc. Natl. Acad. Sci. USA 88:6162-6166.

49. Hann, S. R., C. B. Thompson, and R. N. Eisenman. 1985. c-myc oncogene protein synthesis is independent of the cell cycle in human and avian cells. Nature (London) 314:366-369.

50. Heikkila, R., G. Schwab, E. Wickstrom, S. L. Loke, D. H. Pluznik, R. Watt, and L. M. Neckers. 1987. A c-myc antisense oligodeoxynucleotide inhibits entry into $S$ phase but not progress from G0-G1. Nature (London) 328:445-449.

51. Holt, J. T., R. L. Redner, and A. W. Nienhuis. 1988. An oligomer complementary to c-myc mRNA inhibits proliferation of HL-60 promyelocytic cells and induces differentiation. Mol. Cell. Biol. 8:963-973.

52. Hourdry, J., A. Brulfert, M. Gusse, D. Schoevaert, M. V. Taylor, and M. Mechali. 1988. Localization of c-myc expression during oogenesis and embryonic development in Xenopus laevis. Development 104:631-641.

53. Hunter, T. 1991. Cooperation between oncogenes. Cell 64:249270.

54. Hunter, T., and M. Karin. 1992. The regulation of transcription by phosphorylation. Cell 70:375-387.

55. Jackson, S. P. 1992. Regulating transcription factor activity by phosphorylation. Trends Cell. Biol. 2:104-108.

56. Jaffredo, T., B. Vandenbunder, and F. Dieterlen-Lievre. 1989. In situ study of c-Myc protein expression during avian development. Development 105:679-695.

57. Kaelin, W. G., Jr., D. C. Pallas, J. A. DeCaprio, F. J. Kaye, and D. M. Livingston. 1991. Identification of cellular proteins that can interact specifically with the T/E1A binding region of the retinoblastoma gene product. Cell 64:521-532.

58. Karn, J., J. V. Watson, A. D. Lowe, S. M. Green, and W. Vedeckis. 1989. Regulation of cell cycle duration by $c$-myc levels. Oncogene 4:773-787.

59. Kato, G. J., J. Barrett, M. Villa-Garcia, and C. V. Dang. 1990. An amino-terminal c-Myc domain required for neoplastic transformation activates transcription. Mol. Cell. Biol. 10: 5914-5920.

60. Kato, G. J., and C. V. Dang. 1992. Function of the c-Myc oncoprotein. FASEB J. 6:3065-3072.

61. Kato, G. J., W. M. F. Lee, L. Chen, and C. V. Dang. 1992. Max: functional domains and interaction with c-Myc. Genes Dev. 6:81-92.

62. Kelly, K., B. H. Cochran, C. D. Stiles, and P. Leder. 1983. Cell-specific regulation of the $c$-myc gene by lymphocyte mitogens and platelet-derived growth factor. Cell 35:603-610.

63. Kerkhofi, E., K. Bister, and K. H. Klempnauer. 1991. Sequence-specific DNA binding by Myc proteins. Proc. Natl. Acad. Sci. USA 88:4323-4327.

64. King, M. W., J. M. Roberts, and R. N. Eisenman. 1986. Expression of the c-myc proto-oncogene during development of Xenopus laevis. Mol. Cell. Biol. 6:4499-4508.

65. Kohl, N. E., and H. R. Ruley. 1987. Role of $c-m y c$ in the transformation of REF52 cells by viral and cellular oncogenes. 
Oncogene 2:41-48.

66. Kretzner, L., E. M. Blackwood, and R. N. Eisenman. 1992. Myc and Max proteins possess distinct transcriptional activities. Nature (London) 359:426-429.

67. Kume, T. U., S. Takada, and M. Obinata. 1988. Probability that the commitment of murine erythroleukemia cell differentiation is determined by the $c-m y c$ level. J. Mol. Biol. 202:779786.

68. Langdon, W. Y., A. W. Harris, and S. Cory. 1988. Growth of $\mathrm{E}_{\mu}$-myc B-lymphoid cells in vitro and their evolution towards autonomy. Oncogene Res. 3:271-279.

69. Lin, L.-L., M. Wartmann, A. Y. Lin, J. L. Knopf, A. Seth, and R. J. Davis. 1993. cPLA ${ }_{2}$ is phosphorylated and activated by MAP kinase. Cell 72:269-278.

70. Lüscher, B., and R. N. Eisenman. 1990. New light on Myc and Myb, part 1. Myc. Genes \& Dev. 4:2025-2035.

71. Lüscher, B., and R. N. Eisenman. 1992. Mitosis-specific phosphorylation of the nuclear oncoproteins Myc and Myb. J. Cell Biol. 118:775-784.

72. Lüscher, B., E. A. Kuenzel, E. G. Krebs, and R. N. Eisenman. 1989. Myc oncoproteins are phosphorylated by casein kinase II. EMBO J. 8:1111-1119.

73. Mäkelä, T. P., P. J. Koskinen, I. Västrik, and K. Alitalo. 1992. Alternative forms of Max as enhancers or suppressors of Myc-Ras cotransformation. Science 256:373-377.

74. Marcu, K. B., S. A. Bossone, and A. J. Patel. 1992. myc function and regulation. Annu. Rev. Biochem. 61:809-860.

75. Maruyama, K. S., S. Schiavi, W. Huse, G. L. Johnson, and E. Ruley. 1987. myc and E1A oncogenes alter the responses of PC12 cells to nerve growth factor and block differentiation. Oncogene 1:361-367.

76. Mittnacht, S., and R. A. Weinberg. 1991. G1/S phosphorylation of the retinoblastoma protein is associated with an altered affinity for the nuclear compartment. Cell 65:381-393.

77. Norbury, C., and P. Nurse. 1992. Animal cell cycles and their control. Annu. Rev. Biochem. 61:441-470.

78. Northwood, I. C., F. A. Gonzalez, M. Wartmann, D. L. Raden, and R. J. Davis. 1991. Isolation and characterization of two growth factor-stimulated protein kinases that phosphorylate the epidermal growth factor receptor at threonine 669. J. Biol. Chem. 266:15266-15276.

79. Palmieri, S., P. Kahn, and T. Graf. 1983. Quail embryo fibroblasts transformed by four $v-m y c$ containing virus isolates show enhanced proliferation but are non-tumorigenic. EMBO J. 2:2385-2389.

80. Papoulas, O., N. G. Williams, and R. E. Kingston. 1992. DNA binding activities of c-Myc purified from eukaryotic cells. J. Biol. Chem. 267:10470-10480.

81. Pedrali-Noy, G., S. Soadari, A. Miller-Faures, A. O. A. Miller, J. Kruppa, and G. Koch. 1980. Synchronization of HeLa cell cultures by inhibition of DNA polymerase $\alpha$ with aphidicolin. Nucleic Acids Res. 8:377-387.

82. Penn, L. J. Z., E. M. Laufer, and H. Land. 1990. c-Myc: evidence for multiple regulatory functions. Semin. Cancer Biol. 1:69-87.

83. Pietenpol, J. A., K. Münger, P. M. Howley, R. W. Stein, and H. Moses. 1991. Factor-binding element in the human c-myc promoter involved in transcriptional regulation by transforming growth factor $\beta 1$ and by the retinoblastoma gene product. Proc. Natl. Acad. Sci. USA 88:10227-10231.

84. Pietenpol, J. A., R. W. Stein, E. Moran, P. Yacluk, R. Schlegel, R. M. Lyons, M. R. Pittelkow, K. Munger, P. M. Howley, and H. Moses. 1990. TGF- $\beta 1$ inhibition of $c-m y c$ transcription and growth in keratinocytes is abrogated by viral transforming proteins with pRB binding domains. Cell 61:777-785.

85. Pines, J., and T. Hunter. 1991. Human cyclins A and B1 are differentially located in the cell and undergo cell cycle-dependent nuclear transport. J. Cell. Biol. 115:1-17.

86. Posada, J., and J. A. Cooper. 1992. Requirements for phosphorylation of MAP kinase during meiosis in Xenopus oocytes. Science 255:212-215.

87. Posada, J., J. Sanghera, S. L. Pelech, R. Aefersold, and J. A. Cooper. 1991. Tyrosine phosphorylation and activation of homologous protein kinases during oocyte maturation and mitogenic activation of fibroblasts. Mol. Cell. Biol. 11:25172528.

88. Prendergast, G. C., R. Hopewell, B. J. Gorham, and E. B. Ziff. 1992. Biphasic effect of Max on Myc cotransformation activity and dependence on amino- and carboxy-terminal Max functions. Genes Dev. 6:2429-2439.

89. Prendergast, G. C., D. Lawe, and E. B. Zifi. 1991. Association of Myn, the murine homolog of Max, with c-Myc stimulates methylation-sensitive DNA binding and Ras co-transformation. Cell 65:395-407.

90. Prendergast, G. C., and E. B. Ziff. 1991. Methylation-sensitive sequence-specific DNA binding by the c-Myc basic region. Science 251:186-189.

91. Prendergast, G. C., and E. B. Ziff. 1992. A new bind for Myc. Trends Genet. 8:91-96.

92. Prochownik, E. V., and J. Kukowska. 1986. Deregulated expression of $c-m y c$ by murine erythroleukemia cells prevents differentiation. Nature (London) 322:848-850.

93. Pulverer, B. J., J. M. Kyriakis, J. Avruch, E. Nikolakaki, and J. R. Woodgett. 1991. Phosphorylation of c-Jun mediated by MAP kinases. Nature (London) 353:670-674.

94. Rabbitts, P. H., J. W. Watson, A. Lamond, A. Forster, M. A. Stinson, G. Evan, W. Fischer, E. Athertton, M. A. Sheppard, and T. H. Rabbitts. 1985. Metabolism of $c$-myc gene products: $c-m y c$ mRNA and protein expression in the cell cycle. EMBO J. 4:2009-2015.

95. Roussel, M. F., J. L. Cleveland, S. A. Shurtleff, and C. J. Sherr. 1991. Myc rescue of a mutant CSF-1 receptor impaired in mitogenic signalling. Nature (London) 353:361-363.

96. Rustgi, A. K., N. Dyson, and R. Bernards. 1991. Aminoterminal domains of $\mathrm{c}-\mathrm{Myc}$ and $\mathrm{N}-\mathrm{Myc}$ proteins mediate binding to the retinoblastoma gene product. Nature (London) 352:541-544.

97. Saksela, K., T. P. Mäkelä, K. Hughes, J. R. Woodgett, and K. Alitalo. 1992. Activation of protein kinase $C$ increases phosphorylation of the $L-m y c$ trans-activator domain at a GSK-3 target site. Oncogene 7:347-352.

98. Sanghera, J., H. B. Paddon, and S. L. Pelech. 1991. Role of protein phosphorylation in the maturation-induced activation of a myelin basic protein kinase from sea star oocytes. J. Biol. Chem. 266:6700-6707.

99. Seth, A., E. Alvarez, S. Gupta, and R. J. Davis. 1991. A phosphorylation site located in the $\mathbf{N H}_{2}$-terminal domain of c-Myc increases transactivation of gene expression. J. Biol. Chem. 266:23521-23524.

100. Seth, A., F. A. Gonzalez, S. Gupta, D. L. Raden, and R. J. Davis. 1992. Signal transduction within the nucleus by mitogenactivated protein kinase. J. Biol. Chem. 267:24796-24804.

101. Shi, Y., J. M. Glynn, L. J. Guilbert, T. G. Cotter, R. P. Bissonnette, and D. R. Green. 1992. Role for $c$-myc in activation-induced apoptic cell death in $\mathrm{T}$ cell hybridomas. Science 257:212-214.

102. Shibuya, E. K., T. G. Boulton, M. H. Cobb, and J. V. Ruderman. 1992. Activation of p42 MAP kinase and the release of oocytes from cell cycle arrest. EMBO J. 11:3963-3975.

103. Shibuya, H., M. Yoneyama, J. Ninomiya-Tsuji, K. Matsumoto, and T. Taniguchi. 1992. IL-2 and EGF receptors stimulate the hematopoietic cell cycle via different signaling pathways: demonstration of a novel role for $c-m y c$. Cell 70:57-67.

104. Sorrentino, V., M. D. Drozdoff, M. D. McKinney, L. Zeitz, and E. Fleissner. 1986. Potentiation of growth factor activity by exogeneous $c-m y c$ expression. Proc. Natl. Acad. Sci. USA 83:8167-8171.

105. Stern, D. F., A. B. Roberts, N. S. Roche, M. B. Sporn, and R. A. Weinberg. 1986. Differential responsiveness of $m y c$ - and ras-transfected cells to growth factors: selective stimulation of $m y c$-transfected cells by epidermal growth factor. Mol. Cell. Biol. 6:870-877.

106. Stokoe, D., P. Campbell, S. Nakielny, H. Hidaka, S. J. Leevers, C. J. Marshall, and P. Cohen. 1992. MAPKAP kinase-2; a novel protein kinase activated by mitogen-activated protein kinase. EMBO J. 11:3985-3994. 
107. Street, A. J., E. Blackwood, B. Lüscher, and R. N. Eisenman. 1990. Mutational analysis of the carboxy-terminal casein kinase II phosphorylation site in human c-Myc. Curr. Top. Microbiol. Immunol. 166:251-258.

108. Sturgill, T. W., L. B. Ray, E. Erikson, and J. L. Maller. 1988. Insulin-stimulated MAP-2 kinase phosphorylates and activates ribosomal protein S6 kinase II. Nature (London) 334:715-718.

109. Takishima, K., I. Griswold-Prenner, T. Ingebritsen, and M. R. Rosner. 1991. Epidermal growth factor (EGF) receptor T669 peptide kinase from 3T3-L1 cells is an EGF-stimulated "MAP" kinase. Proc. Natl. Acad. Sci. USA 88:2520-2524.

110. Tamemoto, H., T. Kadowaki, K. Tobe, K. Ueki, T. Ixumi, Y. Chatani, M. Kohno, M. Kasuga, Y. Yazaki, and Y. Akanuma. 1992. Biphasic activation of two mitogen-activated protein kinases during the cell cycle in mammalian cells. J. Biol. Chem. 267:20293-20297.

111. Tate, E. H., M. E. Wilder, S. Cram, and W. Wharton. 1983. A method for staining 3T3 cell nuclei with propidium iodide in hypotonic solution. Cytometry 4:211-215.

112. Thompson, C. B., P. B. Challoner, P. E. Neiman, and $M$. Groudine. 1985. Levels of $c$-myc oncogene mRNA are invariant throughout the cell cycle. Nature (London) 314:363-366.
113. Tobey, R. A., N. Oishi, and H. A. Crissman. 1990. Cell cycle synchronization: reversible induction of G2 synchrony in cultured rodent and human diploid fibroblasts. Proc. Natl. Acad. Sci. USA 87:5104-5108.

114. Torres, R., N. Schreiber-Agus, S. D. Morgenbesser, and R. A. Depinho. 1992. Myc and Max: a putative transcriptional complex in search of a cellular target. Curr. Opin. Cell Biol. 4:468-474.

115. Waitz, W., and P. Loidl. 1991. Cell cycle dependent association of c-Myc protein with the nuclear matrix. Oncogene 6:29-35.

116. Waters, C. M., T. D. Littlewood, D. C. Hancock, J. P. Moore, and G. I. Evan. 1991. c-Myc protein expression in untransformed fibroblasts. Oncogene 6:797-805.

117. Weinberg, R. A. 1991. Tumor suppressor genes. Science 254:1138-1146.

118. Woodford, T. A., and A. B. Pardee. 1986. Histone H1 kinase in exponential and synchronous populations of chinese hamster fibroblasts. J. Biol. Chem. 261:4669-4676.

119. Zervos, A. S., J. Gyuris, and R. Brent. 1993. Mxil, a protein that specifically interacts with Max to bind Myc-Max recognition sites. Cell 72:223-232. 